\title{
Kulttuuriset ajan mallit yliopiston pedagogisessa projektitoiminnassa
}

\author{
VIRVE KALLIONIEMI-CHAMBERS
}

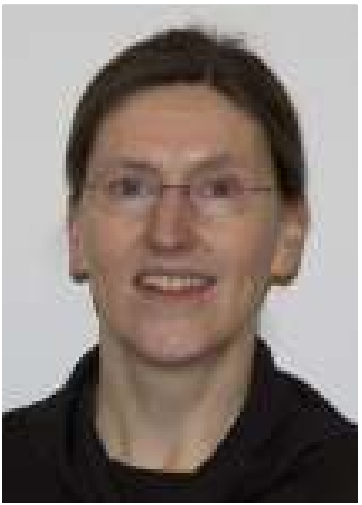

\begin{abstract}
Virve Kallioniemi-Chambersin väitöskirjatutkimuksen kohteena oli pedagoginen yhteistoiminta, jota yliopisto tekee lisääntyvässä määrin erilaisten organisaatioiden ja toimijaosapuolten kanssa. Pedagogisen yhteistoiminnan kulttuurista ulottuvuutta hän käsitteellisti ajan näkökulmasta. Tutkimuksen innoittajana on yliopistotyön vetovoimatekijänä esitetty niin sanottu ajattoman ajan lupaus. Tutkimus kysyy, millainen on yliopiston pedagogisen projektitoiminnan aikakulttuuri. Tutkimus oli tapaustutkimus, jonka kohteena on kaksi yliopiston ammattikasvatuksellista yhteistyöprojektia.
\end{abstract}

Aikakaudellamme havaintomme itsestämme ja maailmasta ovat läpinäkyvästi aikaa, erityisesti kellon aikaa korostavia. Havainnot ovat erilaisia verrattuna elämänmuotoon, jossa esimerkiksi tapaamisista sovitaan toteamalla '... tapaamme, kun aurinko nousee, ...'

Hiljattain valmistuneessa saksalaisessa Franz Schapfel-Kaiserin (2009) tekemässä väitöskirjassa tarkastellaan ammattien aikakulttuuria. Tutkimuksessa kysytään, onko ammateilla oma aika. Schapfel-Kaiserin tutkimuksessa tarkastellaan kätilön, taiteilijan, kiinteistöpäällikön ja veturin kuljettajan työtä ja miten näitä töitä tekevät hahmottavat aikaa työssään. Tuloksissa kuvataan, kuinka veturinkuljettajalla on tarkat aikataulusuunnitelmat, joita hän seuraa. Kätilön on vuorostaan vaikea suunnitella aikataulullisesti työtään, koska syntyminen ja synnyttämisen ajankohdat ovat yllätyksellisiä. Kiinteistöpäällikkö yrittää suunnitella toimet niin, että toimintaan käytetään mahdollisimman vähän aikaa ja pienessä ajassa saadaan mahdollisimman paljon tehdyksi. Taiteilijalle on tärkeää, että hänellä on omaa yksityistä aikaa. Olennaista on pystyä työskentelemään inspiraation ollessa päällä.
Schapfel-Kaiserin tutkimuksessa osoitetaan, että sosiaalisen elämän eri alueilla aika järjestää toimintoja eri tavoin. Koulutuksessa ja terveydenhuollossa aika kiinnittyy läheisemmin luonnon rytmeihin. Kaupan alalla toimintojen prosessit suuntautuvat tulevaisuuteen ja aikaa suhteutetaan näihin visioihin.

\section{Ajattoman ajan lupaus, yliopisto kasvun ja tutkimuksen paikkana}

Yliopisto on oppimisen ja kasvun paikka opiskelijoille, jotka jossain vaiheessa siirtyvät toimijoiksi erilaisiin ympäristöihin, paikkoihin, joissa muun muassa erilaisiin ammatteihin kiinnittyviä aikoja esiintyy. Yliopisto on kasvun paikka myös sieltä palkkansa saaville tutkijoille, hallintohenkilökunnalle ja tukihenkilöstölle. Millainen sitten on yliopiston aikakulttuuri ja miten se määrittää yliopiston toimijoiden oppimista ja kasvua? Kysymyksen lähtökohtana on näkemys siitä, että yliopiston toiminnalla on tietynlainen sisäinen järjestys, jota voi kuvata ajalla. Erilaiset ajat asettuvat keskenään tietynlaiseen järjestykseen siitä riippuen, millaista aikaa pidetään tärkeänä ja millaista vä- 
hemmän tärkeänä. Ilmiön erityinen toimintalogiikka ilmenee tietyntyyppisenä aikana ja ajan järjestyksenä, mistä käytetään myös nimitystä "Eigenzeit" (Nowotny, Ylijoki 2006b, 46).

\section{Hidas ja nopea aika}

Erilaisia aikoja on jäsennetty monitieteellisissä ja eri tieteen alojen tutkimuksissa. Esimerkiksi norjalainen sosiaaliantropologi Eriksen jäsentää nopean ja hitaan ajan järjestykset toistensa vastakohdiksi. Hidasta aikaa kuvaa turvallisuus, ennustettavuus, johonkin kuuluminen sekä kumulatiivinen kasvu (kehitys). Nopean ajan luonnehdintoja ovat epävarmuus ja liikkuvuus.

Yliopiston kulttuurisuutta ajan näkökulmasta on Suomessa tutkinut erityisesti Oili-Helena Ylijoki. Aineistoa on kerätty tutkijan työstä. Tulokset yliopistotutkijan arjesta kertovat siitä, että osa tutkijoista joutuu toistuvasti hakemaan rahoitusta taatakseen jatkuvuutta tutkimustyölleen. Hakemuksia kirjoitetaan lyhyellä aikavälillä. (Nieminen 2005, 235-236.) Tutkijat kokevat työnsä kiireiseksi, mikä ilmenee kiirepuheena ja aikatietoisuutena. Määräaikaiset työsuhteet voimistavat aikataulullista suunnittelua. Työtä kuormittaa myös henkilökohtaisen ajan niukkuus. Ulkoisten odotusten rinnalla tutkijoilla on kuitenkin kokemuksia niin sanotusta ajattomasta ajasta. Kokemus liittyy tilanteisiin, joissa tutkijat ovat voineet uppoutua tutkimukseen eivätkä ulkoiset tekijät ole painostaneet heitä seuraamaan ajan kulumista. (Ylijoki \& Mäntylä 2003a, 130; 2003b; Hakala \& Ylijoki 2000; Silvonen 1996.)

\section{Yliopiston projektit tutkimuskohteena}

Oman tutkimukseni näkökulman kimmoke on tässä yliopistoon perinteisesti liitetyssä niin sanotussa ajattomassa ajassa. Se on innostanut etsimään erityisesti yhteiskuntatieteissä tehtyä tutkimusta aika-teemasta ja rakentamaan ymmärrystä ajasta sosiaalisen elämän rakentajana. Toistaiseksi on vähän tutkimusta, jossa yliopiston opetustoimintaa, jota tutkimuksessani tarkastelen pedagogisena toimintana, tarkasteltaisiin aika-teeman näkökulmasta. Yliopiston yksi tehtävä on antaa ylintä opetusta. Yliopiston ideassa opetus integroituu tutkimukseen. Tämä on siis idea. Idea monipuolistuu, kun näiden kahden tehtävän rinnalla otetaan huomioon yliopiston kolmas tehtävä, vuo- rovaikutus ympäristön kanssa. Yliopisto tekee lisääntyvässä määrin yhteistyötä erilaisten osapuolten kanssa, mitä toteutetaan usein projektirahoituksena.

Työskentelin vuosituhannen vaihteessa Euroopan Unionin rahoittamissa yliopiston projekteissa, joissa suunniteltiin ja toteutettiin vuoden kestävät ammattikasvatuksen opintokokonaisuudet. Osallistuin projekteihin toisaalta projektitutkijana ja yhteyshenkilönä, mutta myös jatko-opiskelijana. Toinen opintokokonaisuus toteutettiin kansallisessa yhteistyössä, jossa toimijoita oli yliopistosta, ammatilliselta opettajakorkeakoululta ja muunlaisista työelämän organisaatioista. Toinen opintokokonaisuus toteutui eurooppalaisten yliopistojen yhteistyönä.

Muutaman vuoden kuluttua projektien päättymisen jälkeen, vuonna 2004, kun olin pohtinut ja tarkastellut projekteista jäänyttä aineistoa, rupesin etsimään mahdollisuutta tulkita projektien toimintaa aika-teeman näkökulmasta. Tarkennetuksi tutkimuskysymyksekseni muotoutui, millainen aikakulttuuri ehdollistaa ja mahdollistaa yliopiston pedagogisen tehtävän projektimaisessa pedagogisessa toiminnassa?

\section{Kulttuuriset ajan mallit}

Olen hakenut ajan ilmaisuja projektitoiminnan erilaisista jäljistä. Näistä löydöksistäni olen tiivistänyt tutkimuksessani ns. kulttuuriset ajan mallit. Mallit eriytyvät toisistaan muun muassa siinä, millainen asema yhteisöllä on toiminnassa ja kuinka vuorovaikutuksellista tai persoonatonta toiminnan hallinta on. Mallit eriytyvät toisistaan myös kiireen suhteen. Kiireen perusta on toisessa mallissa pedagogisissa sisällöissä ja tavoitteissa, toisessa tehokkuudessa, jota mitataan taloudellisin kriteerein. Mallit kertovat projektien aikakulttuurista, jossa elää useanlaista kulttuurisuutta. Projekteissa on nopeaan aikaan kiinnittyvää tehokkuuden ja persoonattomuuden kulttuuria, toisaalta projekteissa on yksilöllisen ajan kulttuuria ja myös yhteisöllisyyttä painottavaa yhteisen ajan ja levollisuuden kulttuuria.

Tehokkuutta ja hyötyä korostavassa kulttuurissa pedagogista toimintaa dominoi kellon aika, löysä aika kitketään pois, ja toiminta ohjautuu persoonattomasti. Tehokkuuden vaatimuksen antaja ei henkilöidy esimerkiksi opettajaan, mutta kaikki tehokkuuden vaatimuksen tunnistaa. Vaatimus tulee jostain ulkopuolelta. Nopea aika korostuu 
ja, kellon ajasta tulee 'äänekäs'. Kellon ajan äänekkyyden mahdollistavat toimijoiden hajanaiset ja keskenään ristiriitaiset sisällölliset tavoitteet ja toimintatavat niihin pääsemisessä. Nopea aika ei jätä toimijoille mahdollisuuksia etsiä toiminnan rytmiin muutosta tilanteissa, jotka vaatisivat hitaampaa asioiden tarkastelua.

Yksilöllisen ajan kulttuurissa pedagogisessa toiminnassa yhteistä aikaa pyritään muokkaamaan yksilöllisten tarpeiden ja ajankäytön käytäntöjen mukaan. Oppijan aika on ensisijainen yhteisen ajan suhteen. Tutkimuksessani esitän huolen sellaista pedagogiikka kohtaan, jossa oppijan kannettavaksi jää useiden erilaisten kontekstien aikojen toisiinsa sovittaminen toisiinsa ilman kokemuksia yhteisöllisyydestä. Kysyn, mikä tällöin estää sen, että tehokkuuden kulttuuri ei muokkaisi pedagogisten tavoitteiden perustaa tehokkuuden intresseihin sopivaksi.

Yhteisen ajan ja levollisuuden kulttuurissa oppijat - niin opettajat, opiskelijat, kuin suunnittelijat - joutuvat tarkistamaan omaa ajan käyttöänsä suhteessa yhteiseen aikaan. Kulttuuria luonnehtii pedagogisiin tavoitteisiin ja toimintatapoihin kiinnittyvä yhteisöllisyys. Toiminnan 'kello' on sisällöissä ja toiminnan tavoitteissa. Ihanteellisimmallaan yhteisö toimii omana kellonaan: kellon aika on uppoutunut toimintaan.

\section{Projektitoiminnan aikakulttuurin monikerroksellisuus}

Tutkimukseni osoittaa, että projektiperustaisen pedagogisen toiminnan aikakulttuuri sisältää monikerroksellisesti useiden kontekstien kulttuurisuutta, joissa toimintaa järjestetään ajalla eri tavoin. Projektitoiminnassa elää rinnakkain erilaisia kulttuureja. Tarkastelemassani projektissa tehokkuuden kulttuuri välittyi pedagogiseen toimintaan erityisesti muista kuin koulutusorganisaatioista. Erilaisten kulttuurien piiloisuus ja tunnistamattomuus tukee sitä, että kulttuurit eivät toiminnassa kohtaa toisiansa vaan kyse on ennemmin törmäyksestä. Ajan termein se tarkoittaa projektitoiminnassa erilaisia ajan järjestyksiä ja niiden keskinäistä kilpailua. Yhteistyö voidaan kokea hämmentävänä, kun kulttuurien moninaisuutta ei huomioida. Kulttuurinen monimuotoisuus ei kuitenkaan koske vain erilaisten organisaatioiden yhteistoimintaa. Useat tiedekulttuuria tarkastelevat tutkimukset osoittavat yliopistossa elävän erilaisia kulttuureja, mikä on toisaalta resurssi, mutta myös haaste monitieteisen yhteistoiminnan lisäämisessä. Englantilainen kasvatustieteilijä Ronald Barnett on kuvannut yliopiston sisäistä monimuotoisuutta kuten myös elämää yleensä sanalla superkompleksinen. Hän arvioi, että nyky-yliopistoissa pyritään vahvistamaan hallintoa, mutta samanaikaisesti tutkijat rakentavat todellisuuden kompleksisuutta tutkimustyöllään, todellisuuden kuvauksillaan ja tulkinnoillaan. Barnett asettaa yliopistolle tehtäväksi toisaalta käsitteiden ja toimintatapojen kehittämisen, jotka auttavat elämään kompleksisuudessa, ja toisaalta sellaisten käytäntöjen etsimisen, jotka vahvistavat yhteisöllisyyttä.

\section{Kasvun ja oppimisen omanlainen aika?}

Yliopistokontekstissa yhteisöllisyyden perustana on ollut vahvasti tieteen tekeminen. Tutkimusperustaisesti yliopiston pedagogisessa yhteistoiminnassa muunlaisten organisaatioiden, ja osapuolten kanssa - ovat ne sitten kansallisia tai kansainvälisiä, tai oli yhteistoiminta sitten monitieteistä yliopiston sisällä - olisi erilaisten käytäntöjen ja prosessien kulttuuristen taustojen ja pedagogisten perustojen selkeyttäminen. Erilaisten prosessien ajallisuuden tunnistaminen ja tunnustaminen on osa tätä tehtävää. Yliopiston opettajat ovat tässä merkittävässä asemassa. Tutkimukseni herättelee tunnistamaan sitä, mikä on kasvun ja oppimisen omanlainen aika niissä prosesseissa, joita he opetustoiminnallaan tavoittelevat. Vaikka kasvun ja oppimisen ns. omaa aikaa on tarkasteltu tutkimuksissa vähän, monissa, keskenään hyvin erilaisia konteksteja tarkastelevissa kasvatustieteellisissä tutkimuksissa luonnehditaan kasvua ajan termein. Huomio kiinnittyy hitaan ajan korostuksiin näiden prosessien luonnehdinnoissa. Esimerkiksi, syvällisiä oppimisen muutoksia on kuvattu hitaiksi, käsitteellinen muutos koetaan hitaaksi ja sykliseksi prosessiksi (ks. Ruohotie 2004, 37.)

Opiskelijat tunnistavat kriittisen reflektion ja sen ohjaamisen prosessiksi, joka edellyttää aikaa (Olstedt 2005). Ohjausprosesseja on kuvattu näkymättömiksi (esim. Onnismaa 2007, 133), mikä vaikeuttaa ohjauksen ajallisten ehtojen määrittämistä. Uudet pedagogiset linjaukset, kuten henkilökohtaisten opintosuunnitelmien muovautuminen ja ohjaaminen, ovat aikaavieviä (Annala 2007). Ryhmäohjautuva oppiminen vuorostaan edellyttää pitkäaikaisia prosesseja, koska vasta silloin on mahdollista kohdata konflikteja ja oppia niiden rat- 
kaisutapoja (Häkämies 2007, 157). Tyypillistä on toimijoiden kuvaukset ajan puutteesta tai esimerkiksi jaksamisen ajallisuuden ja rajallisuuden tunnustamattomuudesta. Heikkinen, Borgman, Henriksson, Korkiakangas, Kuusisto, Nuotio \& Tiilikkala 2001).

Tutkimukseni herättelee keskustelua, millaisessa aikakulttuurissa opiskelijoiden halutaan kasvavan ja oppivan ja mihin suuntaan aikakulttuuri heidän kasvuaan ohjaa? Millaista aikuisuutta yliopisto-opiskelussa rakennetaan aikakulttuurin näkökulmasta?

Tulen tutkimuksessani loppupäätelmiin, joiden mukaan yliopiston pedagoginen toiminta voitaisiin nähdä aiempaa selkeämmin kulttuurisena kasvattajana. Tehokkuuden ja levollisuuden kulttuurit esittävät toiminnan suunnittelijoille, toteuttajille ja opiskelijoille toisiinsa verrattuna erilaisia kysymyksiä pedagogisesta toiminnasta ja sen tavoitteista. Tehokkuuden ja peroonattomuuden kulttuuriin kiinnittyen voi kysyä, missä määrin sivistys ja kasvu ovat yliopistossa ekonomistuneet. Yksilöllisen ajan kulttuuriseen malliin liittyen voi kysyä, lisätäänkö pedagogisilla käytännöillä opiskelijoiden omaa vastuuta opintojensa järjestämisessä ja tiukennetaanko samalla sitä kuvaa, johon opiskelijan tulisi kasvaa, esimerkiksi kuvaan kiireisestä, itseohjautuvasta aikuisesta. (ks. Koski 2004). Yhteisen ajan malli haastaa pureutumaan yhteisöllisyyden perustaan; onko yliopiston yhteisöllisyys tieteen tekemisessä ja sen integroitumisessa opetukseen, vai perustuuko yhteisöllisyys tehokkuuteen, jossa ei viime kädessä ole varaa huomioida pedagogisen toiminnan luonnetta. Tutkimuksessani tulkittuja malleja voi testata ja tarkentaa erilaisissa elinikäisen oppimisen konteksteissa. On tärkeää tietää, onko esimerkiksi taloudellisiin arvoihin kiinnittyvä tehokkuuden ja hyödyn kulttuuri yksilön ja yhteisöjen kasvua vahvimmin määrittävä aikakulttuuri erilaisissa koulutusorganisaatioissa. On myös tärkeää tunnistaa niitä tiloja ja paikkoja, joissa levollisuuden kulttuuri saa tilaa ja vahvistuu.

Lähestyn tutkimukseni päätelmissäni myös pedagogisia kysymyksiä, joita tarkastellaan kansallista ja etnistä monikulttuurisuutta ja kulttuurien välistä osaamista tarkastelevissa tutkimuksissa. Koehn ja Rosenau (2002) käyttävät käsitettä kulttuurien välinen kompetenssi, johon sisältyy kyky kuunnella ja ymmärtää sekä kyky rakentaa luottamusta. Tutkimukseni tuo tähän keskusteluun tarpeen huomioida aikakulttuuriset tekijät, jotka mahdollistavat tai ehkäisevät näiden vuorovaikutustaitojen rakentumista ja harjoittelua.

Aika on osa olemassaoloa jo syntymisen ja kuolemisen välttämättömyyksien kautta. Usein siteerattu kirkkoisä Augustinukselta peräisin olevalla lainaus on tullut hyvin eläväksi tutkimusprosessini kuluessa: 'Mitä on siis aika? Luulen sen tietäväni, jos kukaan ei sitä minulta kysy. Mutta jos joku sitä kysyy ja tahtoisin sen hänelle selittää, en sitä tiedä."

Ajan tietynasteinen tavoittamattomuus tieteen keinoin ei kuitenkaan sulje pois mahdollisuuksia etsiä tapoja ja menetelmiä, joiden avulla ajan merkitystä sosiaalisen elämän rakentamisessa voi tulkita ja jäsentää. Vaikka muun muassa luonnonkatastrofit ja sitä seuraava ihmisten hätä kyseenalaistavat ajan järjestysten ja aikakulttuurin tutkimisen käytännön merkitystä ja vaikuttavuutta, laajassa kontekstissa pidän tärkeänä, että kasvatustieteellisessä tutkimuksissa hyvän elämän pohdinnoissa ja rakentamisessa huomioidaan aiempaa näkyvämmin ihmisen kasvun prosessien ajallisuutta ja elämän rajallisuus.

Näkökulma sopii kasvatustieteiden sekä perinteisiin että monimuotoistuvan sosiaalisen elämän tutkimuskohteisiin. Kansainvälinen tutkimuksellinen yhteistyö teemassa olisi erittäin tärkeää esimerkiksi suomalaisen yliopiston pedagogiikan kuvan terävöittämiseksi. Teema sopii myös monitieteiseksi tutkimusalueeksi, jossa yhteistyökumppaneita löytyisi luontevasti ainakin yhteiskuntatieteilijöistä ja terveys- ja hoitotieteilijöistä.

Lectio praecursoria väitöstutkimuksesta "Kulttuuriset ajan mallit yliopiston pedagogisessa projektitoiminnassa". Kirjoittaja väitteli Tampereen yliopistossa 12.2.2010. 